https://doi.org/10.18485/iipe_conv_conf.2021.ch3

\title{
ISRAEL: THE MIDDLE EAST OBJECTIVES OF THE REGIONAL POWER AFTER THE LEBANON WAR (2006)
}

\author{
Slobodan Janković1
}

\begin{abstract}
The study of the Middle Eastern objectives of Israel as a regional power is divided into five chapters. The introductory chapter presents hypotheses that Israel is a regional power and asks what its regional objectives are. The second chapter is divided into two parts, the first of which explains how current international relations impact theoretical approaches and makes them the product of time, or echo of what is actually happening. As a result, the author contends that the majority of AngloAmerican theoretical production is essentially post-factum and designed to explain only what has already occurred, rather than offering patterns that can explain future interactions among units of the international system. The second part of the chapter presents an overview of the literature on regional powers and offers the minimal definition of a regional power. The third chapter corroborates hypotheses that Israel is a regional power, while the fourth part of the text analyses the Middle Eastern objectives of Israel's policies. The concluding part briefly presents the overview of the current state of objectives that Israel has reached and how Iran remains its strongest contestant.

Keywords: Israel, Middle East, regional power, Israel's Middle Eastern policy.
\end{abstract}

\footnotetext{
${ }^{1}$ Senior Research Fellow, Head of the Centre for Neighbourly and Mediterranean countries; Institute of International Politics and Economics (Serbia). slobodan@diplomacy.bg.ac.rs The paper presents the findings of a study developed as part of the research project entitled "Serbia and Challenges in International Relations in 2021", financed by the Ministry of Education, Science, and Technological Development of the Republic of Serbia, and conducted by the Institute of International Politics and Economics, Belgrade.
} 
Israel is a geographically and demographically small, yet very active and influential country in the Middle East and even outside the region. In recent years, it has expanded its diplomatic network globally and established regional partnerships on a scale never seen before. On July $22^{\text {nd }}$, it was granted Observer Status at the African Union by Moussa Faki, Chairperson of the African Union Commission. ${ }^{2}$ It was one of the African continent's successes because countries on the Black continent typically support Palestinians due to the influence of North African Arab countries and Sahara's Muslim majority countries. ${ }^{3}$ This, as other initiatives of the Jewish state in international fora, is part of a strategic endeavour to garner support, marginalise opponents and affirm its interests and policies in the Middle East. These regional policies, supported by engagement in international organisations and through bilateral diplomacy in other regions, are not new. Yet, the scope of activity tells those analysing the behaviour of official Jerusalem that Israel is a peculiar regional power. The aim of the article is to analyse the regional policy of Israel and try to evaluate its long-term aims. To do so, two preliminary questions must first be addressed: what is a regional power, and how does Israel fit into this category?

The Middle East is maybe the most famous world region, even though it has no universally accepted borders. For the purpose of this paper, the Middle East is defined as a space stretching from Iran (including it) to Libya, and from Egypt and the Arabian Peninsula in the south to Turkey in the north, including it. It is predominantly Muslim, with the notable exception of Israel and, to a lesser extent, Lebanon, i.e., states that occupy important Levantine coasts and correspond to the majority of territories that once comprised Outremer, a mediaeval crusader state. It includes heirs of the Persian and Ottoman empires and is, at the same time, largely the heritage of European powers' colonial policies. This mixture is at the origin of the contemporary region within which Israel acts as a strong country, if not as a regional power.

\footnotetext{
2 "Communiqué du Président de la Commission de l'UA sur l'accréditation de l'État d'Israël", Union Africaine, août 06, 2021, https://au.int/fr/pressreleases/20210806/communiquedu-president-de-la-commission-sur-accreditation-etat-israel (accessed: 13 August 2021).

${ }^{3}$ Nineteen years since the previous Organisation of African Unity was dissolved, Israel had to ask for observer status in the new organisation, i.e., in the African Union.
} 
In order to achieve stated objectives, it is necessary to revisit definitions of regional power and briefly overview literature on the Middle East and North African regional powers. Although Israel has no public strategy for foreign policy nor a national security strategy, this does not mean that strategic planning and thinking are not shaping Israel's policies; they are just not publicly disclosed.

As regards the time frame researched in the text, it starts after the Lebanon summer war in 2006, but it will concentrate particularly on the period after the Arab Spring. The latest Israeli major military action against objectives in Lebanon is a starting point as it did not achieve the goal of at least significantly reducing the military power of Hezbollah, if not defeating it. Much of Israel's activity is dominated by its relations with Iran and its regional influence. Popular support for Iran and Hezbollah grew after the war, and the star of Tehran had a positive image in the broader Islamic world. This outcome was surely negative for decision makers in Jerusalem.

\section{REGIONAL POWER}

\section{A contextual framework for the research concept}

As regards different theorisations over the concept of regional power, it is interesting to note how theoretical frameworks, including so-called grand theories, are just echoes of current behaviour in the international arena. The impossibility of explaining and predicting theoretically founded patterns of behaviour is a general characteristic of most of the theoretical production in the Anglo-American IR field. ${ }^{4}$ That is why in the past seventy years, after significant changes, new theories have arisen to describe and officially explain the post factum changed reality. In that sense, Waltzian explanation and prediction, like the pullulation of post-colonial theories, are among the most hazy, generalized, and ultimately disconnected from real-world political writings. Of course, generalisation is necessary for a theory, but a theory, in order to be such, needs to explain some pattern occurring in the part of reality

\footnotetext{
${ }^{4}$ See detailed critique of the Anglo-American theories of IR in: Slobodan Janković, Слободан Јанковић, Англо-америчка обмана: Да ли је изучавање међународних односа у сукобу са стварношћу?, (Београд: Catena mundi, 2017), 131. (Anglo-American Deceit: are studies of international relations conflicted with reality?)
} 
to which it refers. In 1979, the Western world was shaken after the oil shocks and class clashes, and the communist block seemed stable. For a couple of decades, the Soviets and Americans had the dominant position in international relations after the decadence of France and the United Kingdom as former colonial empires. In this context, bipolar power distribution was proposed as the most stable and thus most durable feature of the international system, and the balance of power as the situation toward which any system will be inclined. But this theory sometimes seems right and sometimes, as in the period 1989-2007, not. Still, a scientific theory explains some phenomena or aspects of the real world and should be confirmed through two basic methods: observation and experiment. Sometimes it is not valid, and sometimes it is. Only ten years after Waltz's book, bipolarity and the balance of power were defunct. Layne indeed envisaged early that unipolarity was an illusion or temporary, and Waltz claimed in 1993 that "bipolarity endures, but in an altered state". Yet, they could not predict that such momentum would last almost two decades. ${ }^{5}$ Waltz even predicted a rapprochement between a declining Russia and a rising great power, Germany. ${ }^{6}$ We can see today how that was erroneous. The explanation that units define the structure is taken from theories outside the field of international relations and not only from microeconomic theory. ${ }^{7}$ It is different with Huntington, who was a long-time practitioner besides his academic tenure, and was directly involved in foreign policy making. He understood international relations more clearly than his purely theoretical colleagues and, already in 1999, could argue that:

"Global politics has thus moved from the bipolar system of the Cold War through a unipolar moment - highlighted by the Gulf War — and is now

\footnotetext{
${ }^{5}$ For that see Layne explanation of why they missed qualities of American hegemony in: Layne, Christopher, "The Unipolar Illusion Revisited: The Coming End of the United States' Unipolar Moment." Quarterly Journal: International Security, vol. 31. no. 2. (Fall 2006), 741. Kenneth N. Waltz, "The Emerging Structure of International Politics", International Security, Vol. 18, No. 2. (Autumn, 1993), 52.

${ }^{6}$ Waltz envisaged the emergence of Japan, Germany, and China as rising great powers and Russia as a declining power, relying solely on nuclear power, "large population, vast resources, and geographic presence in Europe and Asia". In: Kenneth N. Waltz, "The Emerging Structure of International Politics", 52.

${ }^{7}$ Kenneth N. Waltz, Theory of international politics, (Reading, Mass: Addison-Wesley Pub. Co. 1979), 89-97.
} 
passing through one or two uni-multipolar decades before it enters a truly multipolar 21st century". ${ }^{\prime}$

Alexandr Zinoviev (+2006), a Russian philosopher and sociologist, more accurately described the global political process as westernisation leading to the creation of a globally managed structure that would subdue human freedom. ${ }^{9}$ Living in the West as ostracized from the Soviet Union, he criticised the Western society also through his futurologist work. He claimed that ideologues in the West (social scientists) explain to the citizens of the "Western Union" how, why, and what they should think about any of the issues. ${ }^{10}$ In concordance with Zinoviev's view, when it was evident that previous explanations were not enough and, in particular, when the unipolar moment ${ }^{11}$ was waning, ideologues (social scientists) launched the regional power concept.

\section{Definitions and concepts}

Iver Neumann published in 1992 a collection of papers titled "Regional Great Powers in International Politics". The context in which it was published was a changing world with a dissolving USSR. ${ }^{12}$ In order to explain certain behaviours in some regions, the concept of regional power has become more and more welcome. Since then, the understanding of regional power has been conceptualised, mostly without appellative greatness. As Detlef Nolte points out, Buzzan, at the end of the $20^{\text {th }}$ century, dealt with the characteristics of the region, and other authors followed swiftly. ${ }^{13}$ But area

\footnotetext{
${ }^{8}$ Samuel P. Huntington, "The Lonely Superpower", Foreign Affairs, 78(2), (1999), 37.

${ }^{9}$ Александар Зиновјев, Велика раскрсница, (Београд: Наш дом-L’age d’ Homme 1999).

${ }^{10}$ Александр Зиновьев, Глобальный Человейник, 197 (Alexandr Zinoviev, The Global Humant Hill), https://politconservatism.ru/upload/iblock/2ba/2ba0523d98a2a1a579673 a53a1ec519f.pdf (accessed: 20/06/2021).

${ }^{11}$ Charles Krauthammer, "The Unipolar Moment", Foreign Affairs, Vol. 70, No. 1, (Council on Foreign Relations 1990/1991), 23-33

12 Iver B. Neumann, ed, Regional great powers in International Politics, (Palgrave Macmillan; 1st ed. 1992 edition), 210.

${ }^{13}$ It refers to the article: Barry Buzan, The Asia-Pacific: what sort of region in what sort of world?', in Christopher Brook and Anthony McGrew (eds), Asia-Pacific in the New World
} 
studies were formed in the US much earlier, mostly in joint programmes of the US Army and academia. ${ }^{14}$ Regional studies in Europe did not immediately produce the concept of regional power, although it is quite sensible that some distinction in the power of regional countries has been studied many times before. Different regions, from East Asia to the Middle East, South Africa, Latin America, etc., are studied. But there are different definitions of regional power too. When studying regional orders, Lake discerns different models, among them a regional order dominated by one regional power. ${ }^{15}$ Beck, similarly, or essentially equally, like that particular model of Lake, defined regional power as an actor whose

"power capabilities in a region significantly outweigh those of other actors within the same region and whose power is, to a high degree, based on its leadership role... regional powers heavily rely on soft-power skills since... their power capabilities are not sufficient to dominate regional affairs by unilateral measures. Thus, regional powers exert their influence on the basis of cooperation... rather than measures of hard-power politics". ${ }^{16}$

Martin Beck, like some other authors, occasionally considers continents as regions. ${ }^{17}$ Osterud in 1992 wrote on "geopolitical regions", naming Europe, Africa south of the Sahara, the Middle East, North Africa, South America, and

Order, (London: Routledge 1998), 68-87. See footnotes 15 and 16 in: Detlef Nolte, "How to compare regional powers: analytical concepts and research topics", 883.

${ }^{14}$ See more in: Слободан Јанковић, Англо-америчка обмана: Да ли је изучавање међународних односа у сукобу са стварношћу?, (Anglo-American Deceit: are studies of international relations conflicted with reality?), 66-67.

${ }^{15}$ Lake is mostly concentrated on its concept of international hierarchy and writes mostly about dyadic hierarchy in the region where the dominant state may also be an outside actor (the US in the Middle East). Still, this framework also allows for regional countries to be dominant. In: David A. Lake, "Regional Hierarchy: Authority and Local International Order", Review of International Studies, Vol. 35, Globalising the Regional, Regionalising the Global (Feb., 2009), 35-58. doi:10.2307/20542777

${ }^{16}$ Martin Beck, "The Concept of Regional Power as Applied to the Middle East", in Regional Powers in the Middle East: New Constellations after the Arab Revolts, ed. Henner Fuertig (Palgrave Macmillan, 2014), 4.

${ }^{17}$ Martin Beck, "Regional Politics in a Highly Fragmented Region: Israel's Middle East Policies", (2010), 130. 
so on. ${ }^{18}$ Yet, the Middle East, as well as other macro-regions, does not correspond to the continent.

Cooperation rather than confrontation and dominance over other actors in the region is the approach taken later (in 2014, although in 2010 it was slightly more inclusive) by Beck, recalling Nolte's 11 criteria for regional power. By accepting Nolte's criteria, he adheres to the understanding that regional and world hegemony creates stability (concept of cooperative hegemony and power transition theory). But the problem with Nolte is that he also defines some continents as regions (Asia, in particular, as the largest continent), and that he did not try to empirically test his criteria or to mention at least one regional power. ${ }^{19}$

There is also a congruity between the mentioned approaches and Flemes. Flemes argued that there are four pivotal criteria in order to distinguish regional powers: "claim to leadership, power resources, employment of foreign policy instruments, and acceptance of leadership", notably in the same region. This acceptance of leadership and the claim to it are the links between the mentioned authors. After applying such criteria, Beck concluded that there are no regional powers in the Middle East but only "potential regional powers".$^{20}$ The reasoning of Beck, Flemes, and Nolte is highly ideological, based on a postulate of a benevolent hegemon, or at least, a dominating country mostly acting through international institutions and using cooperation rather than coercion. On top of this, the leadership of such a country should be "recognised" by other regional countries and act for the common good (a benevolent hegemon that distributes public goods exists only in an ideologized view of the world). When taking into account the mentioned and other criteria, there is no country in the world that could fulfil them. Thus, Flemes, when analysing the role of South Africa as a regional power, claimed that Nigeria was a secondary regional power, although accepted as a leader by more governments than South Africa. His various arguments in favour of South Africa and against "secondary rogue power" Zimbabwe were actually

\footnotetext{
${ }^{18} \varnothing$ sterud, Øyvind, "Regional Great Powers", in: Regional great powers in International Politics, Iver B. Neumann, ed, 1-15.

${ }^{19}$ Detlef Nolte, "How to compare regional powers: analytical concepts and research topics", Review of International Studies, Vol. 36, No. 4 (October 2010), 893, 894-95, 897-98.

${ }^{20}$ Martin Beck, "The Concept of Regional Power as Applied to the Middle East", 4, 5, 15, 18.
} 
based on its elite's promotion of economic liberalisation, African free trade and promotion of globalisation through activities based on the affirmation of African organisations aimed at continental integration (following the EU model). ${ }^{21}$ Then again, the US's constant use of coercive power both in the military and economic spheres in the ideological world of some authors would deny the US the status of great power and of regional power too! How ludicrous are these claims!?

Given all the previously enumerated criteria, it could be concluded that the concept would be essentially hypothetical and not applicable to the realities of regional politics. This output is not far from the long tradition of ivory tower academic production in international relations. Here I would like to cite the words of the US marine and professor of security studies, Joyner ${ }^{22}$ :

"(a)cademic study of IR has divorced itself from the real world study of the actual conduct of international relations. Those who serve in government and work in the IR-focused think tanks tend to go to the public policy schools rather than mainline PhD programs. And the work being done by academics in IR is largely irrelevant and inaccessible to the policy community. Indeed, I can't remember the last time I picked up a copy of International Studies Quarterly, much less the American Political Science Review. Frankly, I'm not sure I could read those journals at this point if I wanted to". ${ }^{23}$

Of course, there is another mostly shared understanding that "regional powers are actors - notably states - with significant power capabilities which

${ }^{21}$ Flemes argues that Pretoria played a pivotal role in securing the end of Zaire's involvement in Angola's civil war and in the end of the war (DRC), in the war that did not stop until today. See: Daniel Flemes, "Conceptualising Regional Power in International Relations: Lessons from the South African Case" (June 1, 2007). GIGA Research Programme: Violence, Power and Security- GIGA Working Paper No. 53. 37, 38, 42, 4.8

22 Joyner is Professor of Security Studies and Security Studies Department Head at the Command and Staff College, Marine Corps University; a nonresident senior fellow at the Brent Scowcroft Center on Strategy and Security at the Atlantic Council; and the publisher of the blog Outside The Beltway. He published around 200 articles and comments in the New York Times, Foreign Policy, War on the Rocks, The National Interest, Defense One, Christian Science Monitor, The Hill, World Politics Review... See: https: //www.usmcu.edu/About-MCU/Faculty/Faculty-Directory/Joyner/

${ }^{23}$ James Joyner, "Professionalization and Marginalization of International Relations Field", Outside the Beltway March 27, 2012. http://www.outsidethebeltway.com/professionali zation-and-marginalization-of-international-relations-field/ (accessed: 12/03/2014). 
are, to a comparatively great degree, exerted in their regional context". This is a common assumption in a myriad of productions on the concept and role of regional powers. ${ }^{24}$ Differently put, "regional power is a state that projects influence in a specific region... The regional powers display comparatively high military, economic, political, and ideological capabilities, enabling them to shape their regional security agenda. Overall, the terms "middle powers" and "regional powers" convey capacity, hierarchy, influence, and aspiration". ${ }^{25}$ Thus, regional power is a kind of great power but limited to the region of its origin. However, David Mitchell departs from the understanding that only states are units for analysis and brings in non-state actors that connect elites present in states (decision-makers, S.J.) but also transcend them. ${ }^{26} \mathrm{It}$ is what other authors call "transnational capital" or "transnational class/corporate interests". Obviously, transnational capital plays a growing role as states, including the US, try to accommodate its demands. In regional politics, transnational interests at global and regional level certainly do have some role, bigger or smaller. Still, for the purpose of the research on Israel, it is enough to analyse what it as a state unit promotes and what its interests are in the region, whether they rely on elites and other non-state actors in the region and outside of it. Martin Beck and Detlef Nolte listed literature on the concept of regional power. ${ }^{27}$ What seems to be the general characteristic is that there may be more than one regional power, just as there are more great powers at the world level. For example, it is hard to claim that South Africa is a sub-Saharan regional power and Nigeria

\footnotetext{
${ }^{24}$ Martin Beck, "Regional Politics in a Highly Fragmented Region: Israel's Middle East Policies", GIGA Research Programme: Violence, Power and Security, GIGA WP 89/2008, (Hamburg: September 2008), 8.

${ }^{25}$ Şuhnaz Yilmaz, "Middle Powers and Regional Powers", Oxford Bibliographies Online, 27 September 2017, https://www.oxfordbibliographies.com/view/document/obo-9780199 743292/obo-9780199743292-0222.xm|\#obo-9780199743292-0222-bibltem-0010 (accessed August 24, 2021).

${ }^{26}$ David Mitchell, "Regional Power? Yes, but What Kind?", Paper Presented at International Studies Association Asia-Pacific, (Hong Kong: June 25-27, 2016).

${ }^{27}$ But extensively also on regions and regionalism. See: Detlef Nolte, "How to compare regional powers: analytical concepts and research topics", 881-901. Martin Beck, "Regional Politics in a Highly Fragmented Region: Israel's Middle East Policies", in: Regional Leadership in the Global System. Ideas, Interests and Strategies of Regional Powers, ed. Daniel Flemes and Detlef Nolte, (London: Ashgate 2010), 127-148.
} 
is not. To claim that China is a regional power is quite limited. On the one hand, a great power, such as the United States in North America, can also be a regional power. But China, which is undoubtedly a great power, is unable to fulfil the criteria for regional power set forth by Nolte, Flemes, and Beck, especially regarding the acceptance of leadership. Ponižilova, in order to define it, tries to establish the actors' "position within the regional power hierarchy reflecting the distribution of power among countries in the given subsystem". She defines regional power as

"a state that is an integral part of a distinctive, geographically defined region; that in a regional context, reaches a relative preponderance of material resources; that exerts real influence on other actors and thereby influences the regional policy; that realizes its power potential and aims to become a regional leader and that won the recognition of its power status by at least some states in the region and, if necessary, also by world powers". ${ }^{28}$

In addition to the ideational resources favoured by the mentioned authors and partially accepted by Ponižilova, Estradi admits that regional power may pursue different strategies, from highly aggressive to extremely cooperative, which she defines as imperial, hegemonic, and leading. ${ }^{29}$ This is in line with the behaviour of great powers in the global order. This division does not necessarily mean that powers do not employ sets of strategies to achieve their goals in international relations, but the prevalence should be the crucial distinction. Yet, the very distinction should probably be applied only in certain periods. In that sense, China would be a leading great power, and Germany could be a leading regional power in Central Europe. In order to avoid further ambiguities, it is helpful to propose a minimalistic definition of a regional power that partially fits into the previous mentioned definitions but leaves enough space in order to determine the position of the studied actor in regional power relations. Thus, a regional power is a state (or other actor) able to exert influence in the region with comparatively higher military, economic, and political capabilities and a higher ability to employ them than most other actors

\footnotetext{
${ }^{28}$ Martina Ponižilova, "Delimitation of Regional Powers in The Middle East in The 21th and 21st Century", Medzinárodné Vztahy / Journal of International Relations, (Faculty of International Relations, University of Economics in Bratislava), 2016, Volume XIV, Issue 2, 163.

${ }^{29}$ Sandra Destradi, "Regional powers and their strategies: empire, hegemony, and leadership", Review of International Studies, Vol. 36, No. 4 (October 2010), 904.
} 
in the same region. In that vein, it could be said that the Middle East has several regional powers. Regions can be dominated by one hegemonic power, but not necessarily, as already proposed by Lake (as mentioned previously).

Finally, about power. There are mostly two ways to understand it. Either by comparation of stable categories, such as size of territory, economy, population, military and research size and expenditure, or relationally, which is substantively more suited for the meaning of power, which derives from the Latin verb possum (possum, potes, posse, potui), meaning essentially ability and only later arriving at the more contemporary meaning referring to influence others to act according to your own intentions. To qualify power relatively means judging relations between two or more actors. Yet, even the first category, assumed as stable, is also relational as it relates to the same characteristics of other units with which it is compared. The nature of power as relational means that it is essentially a qualitative category and can be understood also by employing phronesis.

\section{ISRAEL AS A MIDDLE EAST REGIONAL POWER}

Israel is territorially and demographically small. Still, one could not but agree with the assertion of Butenschøn, expressed in 1992:

"...no scholar would deny that Israel today, directly or indirectly, has a political-military strength that at least balances its regional Arab contenders and that it plays a role in global politics which is more important than the size and wealth of this country should suggest. Israel is not only the most privileged 'client state' of the United States (in terms of economic and military assistance, strategic cooperation, and trade), but is also involved on its own on the African continent, from Ethiopia to South Africa, as well as in Latin American countries". ${ }^{30}$

Gabellini enumerates a vast gama of examples of Israeli involvement in many crises and wars across the region (but also outside of it). ${ }^{31}$ But Jankovic

\footnotetext{
30 Nils A. Butenschøn, "Israel as a Regional Great Power: Paradoxes of Regional Alienation", in Regional Great Powers in International Politics, ed. Iver B. Neumann (London: Palgrave Macmillan, 1992), 96.

${ }^{31}$ Giacomo Gabellini, Israele. Geopolitica di una piccola, grande potenza, (Cesena: Arianna Editrice 2017), 352.
} 
goes further to point out that not only AIPAC, or the Israel lobby in general, managed to impose or garner support for many US decisions in the Middle East, as Gabellini also showed, but he claims, based on many examples, like testimonies of high-ranking US government officials and after examining the practise of bilateral relations between two countries, that US regional policy has followed Israeli guidance. This leadership of Israel over US regional politics started early, at least since the death of Kennedy. He argues that the strength of the Israeli lobby was already significant in the first decades of the 20th century, but after the death of Franklin Delano Roosevelt, it became for the first time dominant in shaping US Middle East foreign policy, and continued so with pause until the presidency of Johnson. ${ }^{32}$

That Israel is a Middle Eastern regional power capable of challenging or contrasting with its neighbours militarily has been proven in several Arab-Israeli wars. It is the only nuclear power in the region with at least 400 nuclear-armed missiles. ${ }^{33}$ Israel is the world leader in research and development with 4,95\% of GDP yearly expenditure, it is western country in the Middle Eastern world. In the region UAE is second with $1.3 \%$ of GDP expenditure on R\&D, Turkey is third with $0.96 \%$ and Egypt with $0.72 \%$ of GDP is at the fourth place. ${ }^{34}$ It has around 170,000 personnel in active service in its armed forces, plus some 8,000 in paramilitaries. Its army is well trained and constantly engaged in military actions and covert operations involving special units, the navy, and air forces ${ }^{35}$ Site Global Fire Power puts Israel in third place as a military force in the Middle East and North Africa, but Egypt could hardly be ahead of it. Only Turkey and Iran could compete to be militarily above Israel's capabilities in that field, being highly trained and probed in wars (in Syria and Iraq).

${ }^{32}$ Слободан Јанковић, Блискоисточна криза: pam без мира, (Middle East Crisis: war without peace) (Београд: Catena Mundi 2019), 291-93, 319-327, 329.

${ }^{33}$ Gabellini, Israele. Geopolitica di una piccola, grande potenza, 81-84.

${ }^{34}$ According to data for the year 2018 from: "Research and development expenditureCountry rankings", The global economy, https://www.theglobaleconomy.com/rankings/ research_and_development/ and for Iran data: "Research and development expenditure (\% of GDP) - Middle East", Index Mundi, https://www.indexmundi.com/facts/indicators /GB.XPD.RSDV.GD.ZS/map/middle-east (accessed 29/8/2021).

${ }^{35}$ Data on manpower are from the site Global Fire Power, https://www.globalfire power.com/country-military-strength-detail.php?country_id=israel (accessed 29/8/2021). 
The Jewish state operates in the multipolar region (if regarded as a structure per se)..$^{6}$ The Arab Spring did not alter the regional structure in the sense that it remained multipolar. Prior to the waves of regime changes and the mini-world war in Syria, with western intervention in Libya and regional wars in Yemen and Iraq, Turkey, Egypt, Iran, and Saudi Arabia were considered regional powers and still are. ${ }^{37}$

For the argument of acceptance of leadership and cooperation, which are simplified in our definition as the ability to influence other actors, a good example is the Abraham Accords between Israel, Bahrain, and the United Arab Emirates. However, prior to that, during the Netanyahu administration, Israel sought to reopen embassies or establish entirely new diplomatic missions on the African continent. It renewed ties not only with Arab Muslim countries but also with the Republic of Guinea and started relations with Chad. ${ }^{38}$ Not only that Israel did not fulfil any of the requests of Arab countries presented in the United Nations, requests and proposals of the Arab League or the Organisation of Islamic Cooperation regarding Palestine, but in the end, it was recognised first by Egypt (after the Camp David Accords in 1978), then by Jordan (in 1994) and finally by the UAE and Bahrain (in 2020). Israel used the so-called peace process as a tool of cooperation with the United States to alienate its regional adversaries Iran, Iraq (until 2003), Syria, Hezbollah, and Hamas, while continuing to build new houses and settlements in the occupied territories. Israel managed to obstruct the peace process and sideline the Palestine issue in order to develop ties with actors who previously had antiIsraeli standing (from Saudi Arabia to the UAE). Furthermore, the Israeli president was participating, through satellite connection, at the security conference in Abu Dhabi in November 2013, addressing the "Iranian threat" 39 At least since 2016, Israel has cooperated with the Emirates by conducting

\footnotetext{
${ }^{36}$ Martina Ponížilová, "Delimitation of Regional Powers in The Middle East in The 21th and 21st Century", 158.

${ }^{37}$ Ibid, 167.

${ }^{38}$ Raphael Ahren, "Boosting diplomatic drive to Africa, Israel opens embassy in Rwanda", Times of Israel, 1 April 2019, https://www.timesofisrael.com/boosting-diplomatic-driveto-africa-israel-opens-embassy-in-rwanda/ (accessed: 15/4/2020).

${ }^{39}$ Thomas L. Friedman, "Let's Make a Deal", New York Times, November 19, 2013, http://www.nytimes.com/2013/11/20/opinion/friedman-lets-make-a-deal.html, (accessed: 01/12/2013).
} 
secret joint air force exercises. ${ }^{40}$ Secret cooperation with Iraqi Kurds is not official but has been referenced among those researching or operating in the Middle East for years. ${ }^{41}$ Israel is finally, along with Turkey, the only regional country able to conduct military operations and actions on other states' territory without any consequences (attacks on objectives in Syria, Lebanon, and Iraq). Iran, Saudi Arabia, the UAE, and eventually Egypt are also interventionist states in the region, but they are doing so with an official invitation by the government of the country, or at least by some authority (the government in Aden invited Saudi Arabia and the UAE to intervene in the Yemen civil war, and Iraq and Syria called upon Iran for military help). Given all the mentioned facts, Israel is undoubtedly the Middle Eastern regional power.

\section{ISRAELI REGIONAL OBJECTIVES AFTER 2006}

The "Unfinished War"42 in the summer of 2006 between Israel and Hezbollah was fought in the atmosphere of the regional and global campaign against the perceived threat of the "Shia crescent" announced by the Jordanian king Abdullah in $2004 .{ }^{43}$ Some of the reserves for the religious basis of political actions (in this case, the Shia background of Iranian political expansion) are founded on ideological bias ruling in much of Western academia, which refuses to study this for fear of being called Orientalists (or recently, for fear of being called racists).$^{44}$ Early announcement of the said

40 Theodore Karasik and Jacopo Spezia Depretto, "Enemies with Benefits: How Israel and Gulf Monarchies Work Together", Fair Observer, May 03, 2019, https://www.fairobserver. com/region/middle_east_north_africa/israel-gulf-cooperation-council-gulf-newsheadlines-arab-world-news-80384/ (accessed: 2/9/2021).

${ }^{41}$ As I testified in many talks I had with officials from different Islamic countries in the region.

42 Jonathan Spyer, "Lebanon 2006: Unfinished War", Middle East Review of International Affairs, Vol. 12, No. 1 (March 2008), 69-82. Spyer misrepresented the war, trying to minimize the deployment of the Israeli ground army in order to justify the inability of the Israeli army to achieve victory. The result of the war was the strengthening of Hezbollah, both in national and regional popularity and militarily. See in: Janković, "Middle East Crisis: war without peace", 123.

${ }^{43}$ Robin Wright and Peter Baker, "Iraq, Jordan See Threat to Election From Iran", The Washington Post, Dec. 8, 2004.

${ }^{44}$ The French political geographer, Fabrice Balanche, is himself a victim of this ideologically driven politics in academia. Part of the problem can be understood by reading the open 
Shia "menace" fitted into the plan of part of the American elite to subvert regional order in the greater Middle East and overthrow governments or wage war on seven countries. ${ }^{45}$ But the overall campaign against Iran and its regional partners and allies is also part of the Israeli regional policy that has become more and more clear since the Second Lebanon War in 2006.

Meanwhile, an old regional partner entered into a rift with the Jewish state after an incident in which Israeli commandos killed Turkish citizens on board of the Mavi Marmara, a Turkish ship on an official humanitarian mission to break the naval blockade of the Gaza open-air prison in 2010. ${ }^{46}$ Despite the fact that several initiatives to resolve the dispute have been launched in the interim, the two countries remain verbally antagonistic. Recently, Turkish president Erdogan asked for a firm reaction from the UN and Organisation of Islamic Cooperation, saying, "If we do not immediately stop Israel's aggression in Palestine, and especially in Jerusalem, tomorrow everyone will find themselves the target of this brutal mentality" ${ }^{\prime 7}$. Still, this remains a verbal altercation.

Previously, Israel has concentrated efforts on appeasing neighbouring Arab countries or trying to divide them (as is the case with Syria and Lebanon) in parallel with obstructing the Israeli-Palestinian peace process. The fall of the Saddam Hussein regime in Iraq and the US-led occupation since 2003 destabilised another Muslim secular regime in the region that was also a sponsor of the Palestinian Liberation Organisation and a political ally of the Palestinian cause. The Palestinians lost other partners with the subsequent fall of Tunisian and Libyan leadership in the so-called Arab Spring.

letter signed by 100 French scholars and previous hysterical announcements. See: "Open letter: a response from the '100' French scholars", Open Democracy, 25 November 2020. https://www.opendemocracy.net/en/can-europe-make-it/open-letter-response-100french-scholars/ (accessed: 10/09/2021).

45 "Wes Clark- America's Foreign Policy «Coup»", 05.11.2007, Youtube, http://www.youtube. com/watch ?v=TY2DKzastu8 (accessed: 16/05/2011). Taken from: Janković, "Middle East Crisis: war without peace", 150.

${ }^{46}$ Dan Arbell, "The U.S.-Turkey-Israel Triangle", The Center for Middle East Policy at Brookings, Analysis paper, Number 34, October (2014): 1, https://www.brookings.edu/wpcontent/uploads/2016/06/USTurkeylsrael-TriangleFINAL.pdf (accessed: 12/9/2021).

${ }^{47}$ https://www.aa.com.tr/en/world/turkey-will-not-accept-israeli-persecution-even-if-entireworld-ignores-it/2241343 
As the Palestinian issue was waning, Israel could concentrate more on other regional issues, regarding the implementation of the old strategy. In other words, as a Middle Eastern power, Israel uses coercion and cooperation in order to influence regional order. Outlines of never published but discernible strategic policy objectives of the Jewish state could be understood from the fragments of Moshe Sharett's diary, from Yinon's plan, and generally from Israeli actions in the region. The overall strategy would be twofold: 1) appease regional countries and form alliances with them, and 2) weaken regional actors who may pose a threat to the political ambition of securing the Promised Land-Eretz Israel (biblical concept of the Land of Israel). Securing the Promised Land essentially means annexing most of the Western Bank (Judea and Samaria).

Previously, as published by former Israel Ministry of Foreign Affairs employee Oded Yinon, the Jewish state was trying to become a regional power. ${ }^{48}$ In the meantime, as already demonstrated, it achieved that objective. The second part of the strategy is essentially a division of Syria and Iraq. Finally, as Iran became the main sponsor of anti-Israeli or non-Israeli affiliated actors in the region, it became a similar objective of Israeli strategy as Iraq and Syria were before.

By signing US-sponsored accords with Arab states like the UAE, Bahrain, Morocco, and Sudan, Israel achieves two objectives: 1) it isolates those in the Islamic world who are actively opposing the Jewish state, in particular Iran. Indeed, as already noticed, "security alignment between Israel and Arab states aims to create a firewall against expanding Iranian influence" and 2) it creates an additional regional alliance centred upon Jerusalem-Tel Aviv.

The birth of Israel was marked by war, as is the case of many countries. But defeated enemies in the 1948/49 Arab-Israeli War did not perish. Secured peace with Egypt relaxed Israel in the West, as it is the largest neighbour, which is also the major Arab country in terms of population and army size. Besides Egypt, Syria, Jordan, and Iraq were the most serious military threats. But Jordan was founded as a British creation, and it kept strong bonds with the West until today, and was thus inclined to have, if not good, then at least less worse relations with the Jewish state than Damascus or Baghdad did.

${ }^{48}$ Israel Shahak, "The Zionist Plan for the Middle East", Association of Arab-American University Graduates, Inc. Belmont, Massachusetts, 1982 Special Document No. 1. 
Gabellini refers to different authors in sustaining that Jordan, almost since the 1940s, did not intend to annihilate the Jewish state but had limited territorial ambitions ${ }^{49}$ In any case, after Jordan allowed the formation of a Palestinian delegation in peace talks, it was clear that the Hashemite kingdom was heading toward an agreement with the Jewish state.

The Western occupation of Iraq in 2003 was followed by an internal sectarian war among Shia, Sunni, Kurds, and Turkmens. Even the episode of the ascendance and later of havoc and breakdown of the so-called Islamic State (best known as ISIS) additionally endangered Iraq, which thus does not represent, for the time being, the threat to Israel. The multinational war in Syria ${ }^{50}$, which is partially civil and partially military, fits perfectly into Israeli strategies, together with the mentioned internal conflicts and confrontations in Iraq. Yinon publicly propagated the division of regional Islamic countries into smaller states, which would then become satellites of Israel. ${ }^{51}$ Israeli government members planned in 1954 the division of Lebanon and the creation of the Christian satellite country. ${ }^{52}$ Rolling back Syria from Lebanon and changing the regime in Baghdad were explicit in the text of the document prepared as a sort of foreign policy strategy for Israel made by US neocons (partially of Jewish origin in the US) for the first government led by Benyamin Netanyahu in 1996. Besides that, the redefinition of the Middle East was timidly announced..$^{53}$

${ }^{49}$ Gabellini, Israele. Geopolitica di una piccola, grande potenza, 45 . However, this is just one of the interpretations of the engagement of the Jordan Army founded by British military officer Glubb Pasha (John Bagot Glubb). Glubb commanded the Jordan Arab Legion in the period 1939-1956.

${ }^{50}$ Slobodan Janković, "South and East Mediterranean power struggle: cases of Libya and Syria", Review of International Affairs, Apr-Jun 2020, Vol. 71 Issue 1178, 80.

${ }^{51}$ Israel Shahak, "The Zionist Plan for the Middle East", 6-9, 11.

52 Ibid, 3.

53 "... removing Saddam Hussein from power in Iraq — an important Israeli strategic objective in its own right - as a means of foiling Syria's regional ambitions". "And Damascus fears that the 'natural axis' with Israel on one side, central Iraq and Turkey on the other, and Jordan in the center, would squeeze and detach Syria from the Saudi Peninsula. For Syria, this could be the prelude to a redrawing of the map of the Middle East, which would threaten Syria's territorial integrity. Since Iraq's future could affect the strategic balance in the Middle East profoundly, it would be understandable that Israel has an interest in 


\section{Iran in Israel’s focus}

If Israel transformed conflict with Egypt into peace and cooperation, it did so through US mediation and in exchange for land (liberation of the previously occupied Sinai Peninsula) and economic gains (US yearly support and later through Qualified industrial zones-QIZ and their guaranteed export to the US). It achieved peace with Jordan, in exchange for guarantees that were, since 1996, transformed into concrete economic advantages too (QIZ again). ${ }^{54}$ Still, both Arab countries did not officially renounce their backing of the establishment of the Arab state in Palestine, but ceased to actively oppose Israel's policies and occupation. ${ }^{55}$

The conflict between Israel and Iran evolved from an ideological standoff that erupted after the Islamic Revolution in Persia, to a military one with the Iranian support of first Amal and then Hezbollah in Lebanon. The Americanled occupation of Iraq, followed by the civil war in that country, has emphasized internal divisions in the Mesopotamian country. Iran trained and supported many brigades inside the Popular Mobilization Forces (PMF) paramilitary organisations in Iraq, among them Kata'ib Hezbollah and several political forces in its western neighbour. Together with political organisations, various smaller and bigger armed organisations are securing Iranian influence in Iraq, though with differing levels of autonomy. ${ }^{56}$

supporting the Hashemites..."are probably the most illustrative of the intentions of the authors of this document: "A Clean Break: A New Strategy for Securing the Realm", Institute for Advanced Strategic and Political Studies 1996, http://www.iasps.org/strat1.htm, In the year 2011 this address was still valid, but in the meantime this Israeli think-tank ceased to exist in 2017. One of new e-addresses is http://www.ism-italia.org/wp-content/uploads /Institute-for-Advanced-Strategic-and-Political-Studies-1996-A-Clean-Break-A-NewStrategy-for-Securing-the-Realm.pdf (accessed: 5/09/2021).

${ }^{54}$ Daniel Rosenblatt, "Peace and Prosperity: Israel's Qualifying Industrial Zone Agreements with Jordan and Egypt", Global Trade and Customs Journal, N. 15, Issue 3, (2020): 150-158, https://kluwerlawonline.com/journalarticle/Global+Trade+and+Customs+Journal/15.3/GT CJ2020019

${ }^{55}$ Of course, in Israel's view, it is a liberation of Judea and Samaria.

${ }^{56}$ On Iraqi Hezbollah and other PMF see: Tamer Badawi, "How Can Iran's Raisi Engage with Iraq's Defiant Paramilitaries?", ISPI, 15 June 2021. https://www.ispionline.it/en/ pubblicazione/how-can-irans-raisi-engage-iraqs-defiant-paramilitaries-30864 (accessed: 
Since 2010, the United States has been introducing sanctions against Iran and has been pressing other countries to do the same. But ever since Iran managed to sign the Joint Comprehensive Plan of Action (JCPOA) with UN Security Council member states plus Germany in 2015, Netanyahu has been trying to subvert it. ${ }^{57}$ The Trump administration showed discontinuity with previous efforts to reach a compromise with the Iranians through the US unilateral withdrawal from the JCPOA. Recent changes in governments in the United States and Israel in 2021 raise the prospect of an American return to the JCPOA. But new conditions demanded by Washington make it difficult for Iran to accept them. It is still a question if there is good will to return to the agreement or if it is only a pretext for more diplomatically aggressive US policy on Tehran. Elaborating on an eventual Iranian refusal to accept additional conditionality, new Israeli Prime Minister Naftali Bennet is proposing a joint strategy with the US against Iran. ${ }^{58}$

\section{CONCLUDING REMARKS}

Definitions of regional power vary, and some of them are not applicable in the real world. Israel is a peculiar regional power due to its small size in terms of territory and population. Still, the signing of the Abraham Accords affirmed the role of Israel as a regional power. Jerusalem managed to achieve substantial diplomatic goals by signing peace agreements with four Arab countries in one year: Bahrein, the UAE, Sudan, and Morocco. Additionally, Israel succeeded in isolating its adversaries in the Islamic world. Besides cooperation, in this period, Israel continues to use coercion by conducting hundreds, if not more, of air-attacks and other air military missions in Syria

18/08/2021); and in particular Michael Knights, "Back into the Shadows? The Future of Kata'ib Hezbollah and Iran's Other Proxies in Iraq", CTC Sentinel, Volume 13, Issue 10, (October 2020): 1-22.

${ }^{57}$ Udi Evental, "Israel's counter-Iran strategy: Significant accomplishments, but a negative trend", MEl@75 June 23, 2021, https://www.mei.edu/publications/israels-counter-iranstrategy-significant-accomplishments-negative-trend (accessed: 14/9/2021).

58 "Bennett seeking joint US-Israel strategy on Iran if nuclear talks fail - report", Times of Israel, 13 August 2021, https://www.timesofisrael.com/bennett-seeking-joint-us-israelstrategy-on-iran-if-nuclear-talks-fail-report/ (accessed: 6/10/2021). 
and Lebanon in the observed period ${ }^{59}$ It pushes Western sanctions against Iran, Hezbollah, and Syria, by relying on its main partner, the United States. Secret ground operations cannot be documented at the moment, but we can assume that they are carried on, having in mind the history of engagement of the Israeli military special forces outside the country. Thus, Israel fulfils the criteria we set in the proposed definition of a regional power.

The Israeli Middle Eastern strategy of securing the land between the Jordan River and the Mediterranean Sea is substantially unchanged, though Iran remains the main challenger to its regional interests. The role of Iran in contesting Israel's interests is growing as other actors, such as Iraq, Syria, and partially Libya, are weakened. At the same time, Israel managed to further cooperation with Arab monarchies, from Jordan to Saudi Arabia's court and Gulf states by forming an informal coalition against the perceived Shia crescent. This helped Israel gain acceptance not only as a partner, but also as a regional power, in the sense that it shapes regional policy and has other regional entities agree with or follow its lead.

\section{BIBLIOGRAPHY}

"A Clean Break: A New Strategy for Securing the Realm", Institute for Advanced Strategic and Political Studies 1996, http://www.ismitalia.org/wp-content/uploads/Institute-for-Advanced-Strategic-andPolitical-Studies-1996-A-Clean-Break-A-New-Strategy-for-Securing-the-Re alm.pdf (accessed: 5/09/2021).

Dan Arbell, "The U.S.-Turkey-Israel Triangle", The Center for Middle East Policy at Brookings, Analysis paper, Number 34, October (2014): 1, https://www.brookings.edu/wp-content/uploads/2016/06/USTurkey Israel-TriangleFINAL.pdf (accessed: 12/9/2021)

Badawi, Tamer, "How Can Iran's Raisi Engage with Iraq's Defiant Paramilitaries?", ISPI, 15 June 2021. https://www.ispionline.it/en/ pubblicazione/how-can-irans-raisi-engage-iraqs-defiant-paramilitaries30864 (accessed: 18/08/2021).

\footnotetext{
${ }^{59}$ Suleiman Al-Khalidi, "Israel intensifying air war in Syria against Iranian encroachment", Reuters April 22, 2021, https://www.reuters.com/world/middle-east/israel-intensifyingair-war-syria-against-iranian-encroachment-2021-04-22/ (accessed: 13/9/2021).
} 
Beck, Martin, "Regional Politics in a Highly Fragmented Region: Israel's Middle East Policies", GIGA Research Programme: Violence, Power and Security, Working paper N. 89, 29. Hamburg: September 2008.

Beck, Martin, "Regional Politics in a Highly Fragmented Region: Israel's Middle East Policies", in: Regional Leadership in the Global System. Ideas, Interests and Strategies of Regional Powers, edited by Daniel Flemes and Detlef Nolte, 127-148. London: Ashgate 2010.

Beck, Martin, "The Concept of Regional Power as Applied to the Middle East", in Regional Powers in the Middle East: New Constellations after the Arab Revolts, edited by Henner Fuertig, 1-20. Palgrave Macmillan, 2014. (The Modern Muslim World).

Butenschøn, Nils A., "Israel as a Regional Great Power: Paradoxes of Regional Alienation", in Regional Great Powers in International Politics, edited by Iver B. Neumann, 95-119. London: Palgrave Macmillan, 1992. DOI 10.1007/978-1-349-12661-3

Buzan, Barry, "The Asia-Pacific: what sort region in what sort of world?", in Asia-Pacific in the New World Order, edited by Christopher Brook and Anthony McGrew, 68-87. London: Routledge 1998.

Destradi, Sandra, "Regional powers and their strategies: empire, hegemony, and leadership", Review of International Studies, Vol. 36, No. 4, October 2010, 903-930. doi:10.2307/40961960

Flemes, Daniel, "Conceptualising Regional Power in International Relations: Lessons from the South African Case" (June 1, 2007). GIGA Working Paper No. 53. http://dx.doi.org/10.2139/ssrn.1000123

Friedman, Thomas L, "Let's Make a Deal", New York Times, November 19, 2013, http://www. nytimes.com/2013/11/20/opinion/friedman-letsmake-a-deal.html, (accessed: 01/12/2013).

Gabellini, Giacomo, Israele. Geopolitica di una piccola, grande potenza, Cesena: Arianna Editrice 2017, 352.

Јанковић, Слободан, Англо-америчка обмана: Да ли је изучавање међународних односа у сукобу са стварношћу?, Београд: Catena mundi, 2017, 131.

Јанковић, Слободан, Блискоисточна криза: pam без мира, (Middle East Crisis: war without peace) Београд: Catena Mundi 2019, 397. 
Janković, Slobodan, "South and East Mediterranean power struggle: cases of Libya and Syria", Review of International Affairs, Apr-Jun 2020, Vol. 71 Issue 1178, pp. 79-97.

Karasik, Theodore, and Jacopo Spezia Depretto, "Enemies with Benefits: How Israel and Gulf Monarchies Work Together", Fair Observer, May 03, 2019, https://www.fairobserver.com/region/middle_east_north_africa/israelgulf-cooperation-council-gulf-news-headlines-arab-world-news-80384/ (accessed: 2/9/2021).

Knights, Michael, "Back into the Shadows? The Future of Kata'ib Hezbollah and Iran's Other Proxies in Iraq", CTC Sentinel, October 2020, Volume 13, Issue 10, 1-22.

Krauthammer, Charles "The Unipolar Moment", Foreign Affairs, Vol. 70, No. 1, Council on Foreign Relations 1990/1991, 23-33.

Lake, David A., "Regional Hierarchy: Authority and Local International Order", Review of International Studies, Vol. 35, Globalising the Regional, Regionalising the Global, Feb., 2009, 35-58. doi:10.2307/20542777

Layne, Christopher, "The Unipolar Illusion Revisited: The Coming End of the United States' Unipolar Moment." Quarterly Journal: International Security, vol. 31. no. 2. Fall 2006, 7-41.

Mitchell, David, "Regional Power? Yes, but What Kind?", Paper Presented at International Studies Association Asia-Pacific, Hong Kong: June 25-27, 2016. http://web.isanet.org/Web/Conferences/AP\%20Hong\%20Kong\% 202016/Archive/a6e97a55-34b4-4b63-9f95-2b7c47f2a231.pdf accessed: 15/7/2021.

Neumann, Iver B. ed, Regional great powers in International Politics, Palgrave Macmillan; 1st ed. 1992, 210.

Nolte, Detlef, "How to compare regional powers: analytical concepts and research topics", Review of International Studies, Vol. 36, No. 4 (October 2010), 881-901.

Ponižilova, Martina, "Delimitation of Regional Powers in The Middle East in The 21th and 21st Century", Medzinárodné Vztahy / Journal of International Relations, (Faculty of International Relations, University of Economics in Bratislava), 2016, Volume XIV, Issue 2, 157-185.

Rosenblatt, Daniel, "Peace and Prosperity: Israel's Qualifying Industrial Zone Agreements with Jordan and Egypt", (2020), 15, Global Trade and 
Customs Journal, Issue 3, pp. 150-158, https://kluwerlawonline.com/ journalarticle/Global+Trade+and+Customs+Journal/15.3/GTCJ2020019

Shahak, Israel, "The Zionist Plan for the Middle East", Association of ArabAmerican University Graduates, Inc. Belmont, Massachusetts, 1982 Special Document No. 1.

Huntington, Samuel P., "The Lonely Superpower", Foreign Affairs, Vol. 78, No. 2, (Council on Foreign Relations March/April 1999): 35-49. doi:10.2307/20049207

Waltz, Kenneth N, Theory of international politics, (Reading, Mass: AddisonWesley Pub. Co. 1979)

Waltz, Kenneth N, "The Emerging Structure of International Politics", International Security, Vol. 18, No. 2. (Autumn, 1993): 44-79.

Wright, Robin, and Peter Baker, "Iraq, Jordan See Threat to Election From Iran", The Washington Post, Dec. 8, 2004.

Зиновјев Александар, Велика раскрсница, (Београд: Наш дом-L'age d' Homme 1999).

Зиновјев Александар, Глобальный Человейник, 197 (Alexandr Zinoviev, The Global Humant Hill), https://politconservatism.ru/upload/iblock/2ba/ 2ba0523d98a2a1a579673a53a1ec519f.pdf (accessed: 20/06/2021).

\section{Internet sources}

Raphael Ahren, "Boosting diplomatic drive to Africa, Israel opens embassy in Rwanda", Times of Israel, 1 April 2019, https://www.timesofisrael.com/ boosting-diplomatic-drive-to-africa-israel-opens-embassy-in-rwanda/ (accessed: 15/4/2020).

Al-Khalidi, Suleiman, "Israel intensifying air war in Syria against Iranian encroachment", Reuters April 22, 2021, https://www.reuters.com/ world/middle-east/israel-intensifying-air-war-syria-against-iranianencroachment-2021-04-22/ (accessed: 13/9/2021).

"Communiqué du Président de la Commission de l'UA sur l'accréditation de l'État d'Israël", Union Africaine, août 06, 2021, https://au.int/fr/ pressreleases/20210806/communique-du-president-de-la-commissionsur-accreditation-etat-israel (accessed: 13 August 2021). 
Evental, Udi, "Israel's counter-Iran strategy: Significant accomplishments, but a negative trend", MEl@75 June 23, 2021, https://www.mei.edu/ publications/israels-counter-iran-strategy-significant-accomplishmentsnegative-trend (accessed: 14/9/2021).

Global Fire Power, https://www.globalfirepower.com/country-militarystrength-detail.php?country_id=israel (accessed 29/8/2021).

Joyner, James, "Professionalization and Marginalization of International Relations Field", Outside the Beltway, March 27, 2012, Internet, http://www.outsidethebeltway.com/professionalization-and-marginalization-of-international-relations-field/ (accessed: 12/03/2014).

"Open letter: a response from the '100' French scholars", Open Democracy, 25 November 2020. https://www.opendemocracy.net/en/can-europemake-it/open-letter-response-100-french-scholars/accessed: 10/09/2021.

"Research and development expenditure - Country rankings", The global economy, https://www.theglobaleconomy.com/rankings/research_and_ development/ (accessed 29/8/2021).

"Research and development expenditure (\% of GDP) - Middle East", Index Mundi, https://www.indexmundi.com/facts/indicators/GB.XPD.RSDV.GD. ZS/map/middle-east (accessed 29/8/2021).

"Wes Clark - America's Foreign Policy "Coup»", 05. 11. 2007, Youtube, http://www. youtube. com/watch ?v=TY2DKzastu8, (accessed: 16/05/ 2011). Taken from: Janković, "Middle East Crisis: war without peace", 150.

Yilmaz, Şuhnaz, "Middle Powers and Regional Powers", Oxford Bibliographies Online, 27 September 2017, https://www.oxfordbibliographies.com/view/ document/obo-9780199743292/obo-9780199743292-0222.xml\#obo9780199743292-0222-bibltem-0010 (accessed August 24, 2021). DOI: 10.1093/OBO/9780199743292-0222 